\title{
Mycobacterium branderi sp. nov., a New Potential Human Pathogen
}

\author{
PIRKKO KOUKILA-KÄHKÖLÄ, ${ }^{1,2}$ BURKHARDT SPRINGER ${ }^{3}$ ERIK C. BÖTTGER, ${ }^{3}$ \\ LARS PAULIN, ${ }^{1}$ ERIK JANTZEN, ${ }^{4}$ AND MARJA-LEENA KATILA ${ }^{5 *}$ \\ Institute of Biotechnology, University of Helsinki, 00014 Helsinki, ${ }^{1}$ Laboratory Department, Helsinki University \\ Hospital, 00250 Helsinki, ${ }^{2}$ and Clinical Microbiology, Kuopio University Hospital, 70211 Kuopio, ${ }^{5}$ \\ Finland; Institute for Medical Microbiology, Medical School, 30625 Hannover, Germany; \\ and Department of Vaccine, National Institute of Public Health, 0461 Oslo, Norway ${ }^{4}$
}

\begin{abstract}
A number of mycobacterial strains with similar growth characteristics, metabolic properties, and lipid compositions, which were previously placed in the Helsinki group (E. Brander, E. Jantzen, R. Huttunen, A. Juntunen, and M.-L. Katila, J. Clin. Microbiol. 30:1972-1975, 1992), were characterized by performing 16S rRNA gene sequencing. Of the 14 strains studied, 9 had a unique, previously undescribed sequence in the variable region of $16 S$ rRNA. These nine strains, all of which were isolated from respiratory tract specimens, were nonpigmented and grew at $25 \mathrm{C}$ to $45^{\circ} \mathrm{C}$, reaching full colony size after 2 to 3 weeks. They produced arylsulfatase, nicotinamidase, and pyrazinamidase and were negative for Tween 80 hydrolysis, catalase, urease, and nitrate reductase activities, and niacin. Their glycolipid patterns were identical. A mycolic acid analysis performed by using thin-layer chromatography showed that these organisms contained alpha-mycolates, ketomycolates, and carboxy mycolates. Gas-liquid chromatography revealed that 2-eicosanol was the major alcohol and hexacosanoic acid was the major mycolic acid cleavage product. On the basis of their growth, biochemical, and lipid characteristics and their unique 16S rRNA sequence, we propose that these organisms should be assigned to a new species, Mycobacterium branderi. Comparative 16S rRNA sequencing revealed that this new species is closely related to Mycobacterium celatum, Mycobacterium cookii, and Mycobacterium xenopi. Strains $52157^{\mathrm{T}}(\mathrm{T}=$ type strain) and 43548 have been deposited in the American Type Culture Collection as strains ATCC 51789 and ATCC 51788, respectively.
\end{abstract}

The taxonomic position of a collection of 14 strains of slowly growing mycobacteria that were identified previously on the basis of biochemical activity and lipid composition as members of a potential new species (the "Helsinki group") (3) was determined by analyzing of their $16 \mathrm{~S}$ rRNA gene sequences. These strains were isolated from clinical samples in Finland between 1972 and 1990 and were stored at $-70^{\circ} \mathrm{C}$ because their taxonomic identities were ambiguous. These organisms resembled Mycobacterium xenopi, members of the Mycobacterium avium complex, and Mycobacterium shimoidei in growth characteristics $(3,20)$ but could be distinguished from them by their fatty acid and alcohol compositions and the results of glycolipid analyses. By using gene sequencing, the group was found to comprise two genetic entities, one identical to the recently described species Mycobacterium celatum (4) and the other an undescribed taxon. In this paper we describe the

TABLE 1. Characteristics that distinguish $M$. branderi from some important slowly growing species ${ }^{a}$

\begin{tabular}{|c|c|c|c|c|c|c|c|c|}
\hline \multirow{2}{*}{ Taxon } & \multicolumn{2}{|c|}{ Growth at: } & \multirow{2}{*}{$\begin{array}{l}\text { Pigment production } \\
\text { in the dark }\end{array}$} & \multirow{2}{*}{$\begin{array}{l}\text { Arylsulfatase } \\
\text { activity }^{b}\end{array}$} & \multirow{2}{*}{$\begin{array}{l}\text { Tween } 80 \\
\text { hydrolysis }\end{array}$} & \multirow{2}{*}{$\begin{array}{l}\text { Urease } \\
\text { activity }\end{array}$} & \multirow{2}{*}{$\begin{array}{l}\text { Nitrate reductase } \\
\text { activity }\end{array}$} & \multirow{2}{*}{$\begin{array}{l}\text { Catalase } \\
\text { activity }^{c}\end{array}$} \\
\hline & $25^{\circ} \mathrm{C}$ & $45^{\circ} \mathrm{C}$ & & & & & & \\
\hline M. branderi ${ }^{d}$ & $+^{e}$ & + & - & + & - & - & - & - \\
\hline M. avium & + & V & V & V & - & - & - & - \\
\hline M. celatumf & + & + & - & + & - & - & - & - \\
\hline M. cookii & + & - & + & + & - & - & - & + \\
\hline M. intracellulare & + & V & $\mathbf{V}$ & + & - & - & - & - \\
\hline M. shimoidei & V & + & - & - & + & - & - & - \\
\hline M. scrofulaceum & + & V & + & $\mathrm{V}$ & - & + & - & + \\
\hline M. simiae & + & - & - & - & - & + & - & + \\
\hline M. szulgai & + & - & + & V & V & + & + & + \\
\hline M. terrae complex & + & - & - & V & + & - & V & + \\
\hline M. xenopi & - & + & + & + & - & - & - & - \\
\hline
\end{tabular}

${ }^{a}$ The data for all taxa except $M$. branderi and $M$. celatum are from references $7,11,17,20$, and 21 .

b 14-day test.

${ }^{c}$ Semiquantitative catalase test $(<45 \mathrm{~mm}$ was a negative reaction).

${ }^{d}$ Results of analyses of nine strains whose sequences were identical. The catalase test was negative $(<30 \mathrm{~mm})$ for all strains. In the nicotinamidase and pyrazinamidase tests, the strains exhibited trace to $2+$ reactions.

${ }^{e}$ Symbols: + , more than $80 \%$ of the strains were positive; V, variable reactions;,$- 15 \%$ or less of the strains were positive.

${ }^{f}$ Results of analyses of five strains whose sequences were identical. The strains were negative for catalase $(<30 \mathrm{~mm})$. In nicotinamidase and pyrazinamidase tests the strains exhibited trace to $1+$ reactions.

\footnotetext{
* Corresponding author. Mailing address: Clinical Microbiology, Kuopio University Hospital, P.O. Box 1777, 70211 Kuopio, Finland.

Fax: 358-71-17 32 02. Phone: 358-71-17 3210.
} 
TABLE 2. Fatty acid and alcohol markers used for the initial separation of the Helsinki group (M. branderi and $M$. celatum)

from some important nonchromogenic and scotochromogenic slowly growing species

\begin{tabular}{|c|c|c|c|c|c|c|c|c|}
\hline \multirow{2}{*}{ Taxon } & \multirow{2}{*}{$\begin{array}{l}\text { No. of } \\
\text { strains }\end{array}$} & \multicolumn{7}{|c|}{ Mean peak area $\%$ of: } \\
\hline & & $10 \mathrm{Me}-18: 0$ & 2-OH-20:0alc & 2-Me-20:0 & 2-OH-22:0alc & $24: 0$ & 2,4,6-triMe-24:0 & $26: 0$ \\
\hline M. branderi & 9 & 19 & 8 & $\mathrm{ND}^{a}$ & ND & 4 & ND & 8 \\
\hline M. celatum & 5 & 20 & 10 & ND & ND & 4 & ND & 6 \\
\hline M. avium complex ${ }^{b}$ & 14 & 14 & 9 & ND & ND & 6 & ND & ND \\
\hline M. malmoense ${ }^{b}$ & 14 & 14 & ND & 3 & ND & 2 & 3 & 8 \\
\hline M. shimoidei ${ }^{b}$ & 4 & 10 & 5 & ND & 2 & 6 & ND & ND \\
\hline M. terrae & 7 & 10 & 11 & ND & ND & 7 & ND & ND \\
\hline M. xenopi $i^{b}$ & 14 & 24 & 2 & ND & 11 & 11 & ND & 7 \\
\hline
\end{tabular}

${ }^{a} \mathrm{ND}$, not detected in significant amount.

${ }^{b}$ See reference 3 .

characteristics of the latter taxon and its phylogenetic position in the genus Mycobacterium, and we propose that this taxon is a new species, Mycobacterium branderi.

\section{MATERIALS AND METHODS}

Bacterial strains. Fourteen strains belonging to a previously described collection, the Helsinki group (3), were obtained from storage at $-70^{\circ} \mathrm{C}$ for $16 \mathrm{~S}$ rRNA sequence determinations. Three nonpigmented strains (strains $52157^{\mathrm{T}}$ [ $\mathbf{T}=$ type strain], 38426, and $\mathrm{J} 249$ ) and three strains that produced a yellow pigment (strains 9220,17410, and 28970) were subcultured for three to five subpopulations; each subculture was grown from a single colony. The subcultures were analyzed to determine their fatty acid and alcohol compositions as described previously (3), and when subcultures were found to be identical, one subculture of each strain was randomly selected for 16S rRNA gene sequencing. The sequences of the other strains were determined by using the original bacterial populations.

Preliminary identification. The growth and biochemical characteristics used initially to separate the Helsinki group from other grossly similar slowly growing species are shown in Table 1 . The methods which we used have been described previously (3).

Lipid analyses. Lipid analyses were carried out by using three complementary techniques. Glycolipids were analyzed by one-dimensional thin-layer chromatography $(3,10)$, mycolic acids were analyzed by two-dimensional thin-layer chromatography (3), and fatty acid methyl esters, alcohols, and mycolic acid cleavage products were analyzed by capillary gas-liquid chromatography (GLC) as described previously (3) by using a Perkin-Elmer Autosystem chromatograph (Perkin-Elmer, Norwalk, Conn.).

rRNA gene sequencing and phylogenetic analysis. Nucleic acids were extracted as described previously $(12,16)$. The $16 \mathrm{~S}$ rRNA gene was amplified by using the PCR technique, and the sequence was determined as described previously $(1,12,14)$ by using the solid-phase method $(8)$. Sequencing reactions were performed either manually or with an automated A.L.F. DNA sequencer (Pharmacia, Uppsala, Sweden). In case of automated sequencing, the sequences were assembled by using the Staden Package program (5) and a Sun workstation. In the sequencing strategy which we used, the nucleotides of each isolate were

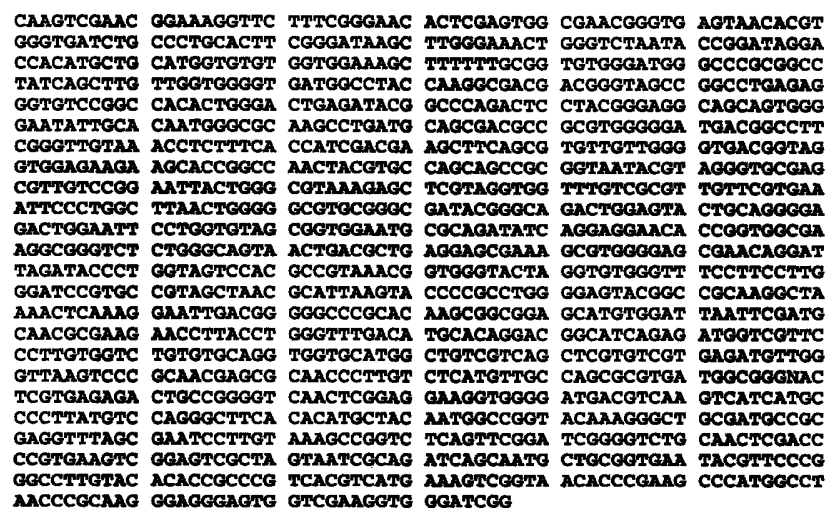

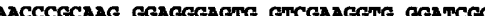

FIG. 1. Partial 16S rRNA gene sequence of strain $52157^{\mathrm{T}}$ (total length, 1,416 bp), which contains 301 adenosine residues, 332 cytidine residues, 492 guanosine residues, and 291 thymidine residues. determined at 1,416 contiguous positions. The sequence obtained was aligned with selected $16 \mathrm{~S}$ rRNA sequences $(6,12)$ as previously described $(15)$. Regions of alignment uncertainty were omitted in the phylogenetic analysis. Pairwise distances were calculated by weighting nucleotide differences and insertionsdeletions (Hamming distances). A phylogenetic tree was constructed by using a neighborness method (18) as previously described.

Nucleotide sequence accession number. The 16S rRNA sequence of $M$ branderi has been deposited in the EMBL database under accession number $\mathrm{X} 82234$.

\section{RESULTS AND DISCUSSION}

The key characteristics used for the initial separation of the Helsinki group strains from other slowly growing species were as follows: wide temperature range for growth (from room temperature to $45^{\circ} \mathrm{C}$ ), strongly positive 14-day arylsulfatase test, negative Tween 80 hydrolysis reaction (Table 1), susceptibility to ethambutol combined with resistance to isoniazid

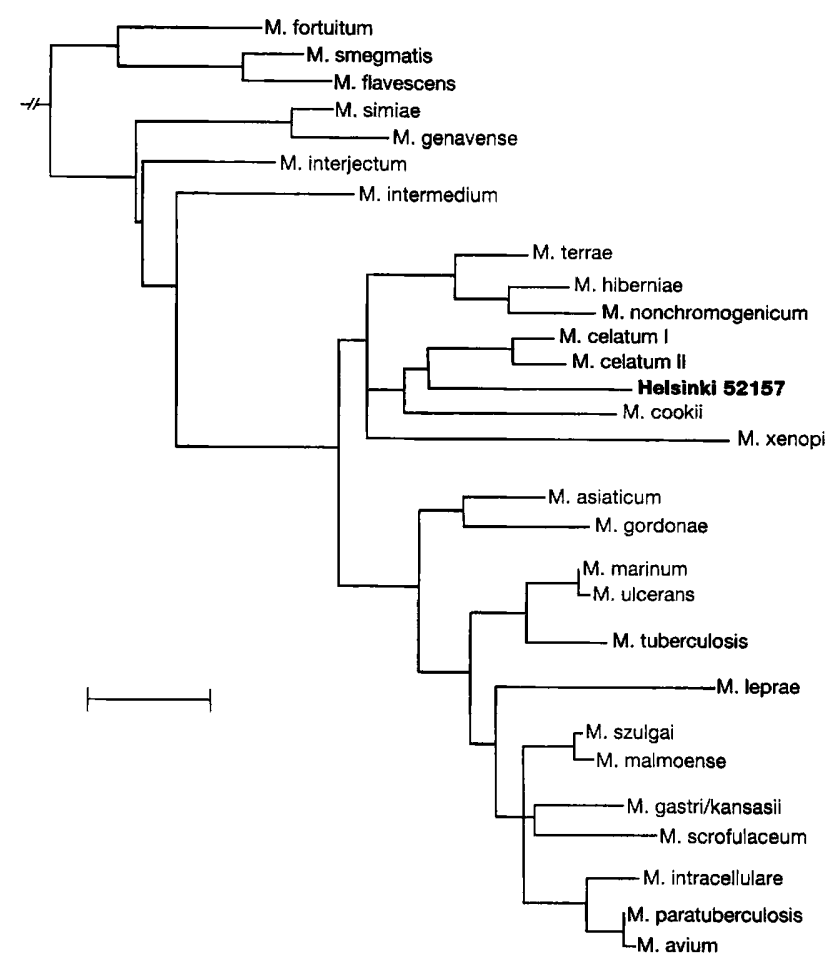

FIG. 2. Phylogenetic tree based on 16S rRNA sequences showing the position of $M$. branderi sp. nov. (Helsinki 52157) among members of the genus Mycobacterium. Bar $=10$ nucleotide differences. 


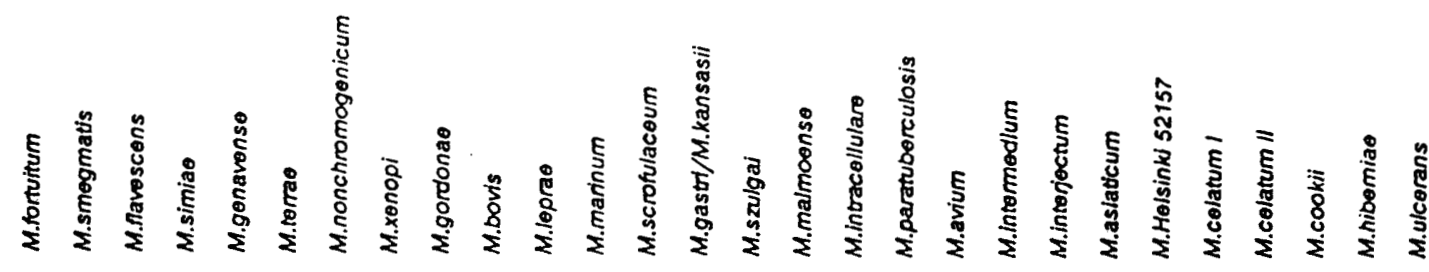

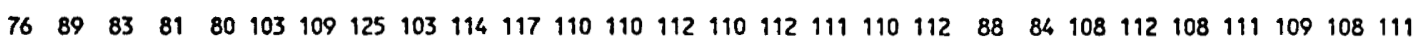

$\begin{array}{lllllllllllllllllllllllllllll}30 & 26 & 46 & 46 & 47 & 51 & 79 & 65 & 63 & 76 & 57 & 65 & 69 & 67 & 67 & 72 & 70 & 71 & 47 & 44 & 62 & 68 & 60 & 62 & 66 & 51 & 58\end{array}$ $\begin{array}{lllllllllllllllllllllllllll}12 & 45 & 49 & 51 & 57 & 80 & 63 & 66 & 75 & 65 & 65 & 69 & 68 & 68 & 71 & 70 & 71 & 48 & 44 & 64 & 75 & 67 & 67 & 68 & 59 & 66\end{array}$ $\begin{array}{lllllllllllllllllllllllll}44 & 47 & 52 & 56 & 83 & 68 & 72 & 79 & 71 & 71 & 75 & 72 & 72 & 76 & 76 & 77 & 49 & 43 & 68 & 79 & 70 & 71 & 69 & 60 & 72\end{array}$ $\begin{array}{llllllllllllllllllllllll}11 & 57 & 64 & 78 & 48 & 59 & 62 & 58 & 43 & 47 & 46 & 46 & 52 & 52 & 53 & 28 & 15 & 44 & 61 & 56 & 58 & 62 & 63 & 59\end{array}$ $\begin{array}{lllllllllllllllllllllll}56 & 68 & 82 & 52 & 62 & 69 & 61 & 54 & 58 & 54 & 54 & 60 & 55 & 56 & 38 & 23 & 47 & 67 & 57 & 60 & 61 & 67 & 62\end{array}$ $\begin{array}{llllllllllllllllllllll}23 & 56 & 37 & 38 & 55 & 35 & 53 & 46 & 45 & 47 & 47 & 46 & 47 & 61 & 55 & 34 & 52 & 39 & 40 & 42 & 20 & 36\end{array}$ $\begin{array}{lllllllllllllllllllll}64 & 49 & 50 & 60 & 46 & 56 & 55 & 51 & 51 & 53 & 50 & 51 & 68 & 63 & 47 & 52 & 53 & 52 & 42 & 16 & 47\end{array}$ $\begin{array}{llllllllllllllllllll}66 & 57 & 68 & 59 & 68 & 64 & 61 & 63 & 63 & 65 & 66 & 76 & 78 & 65 & 67 & 55 & 58 & 69 & 63 & 60\end{array}$ $\begin{array}{lllllllllllllllllll}34 & 42 & 30 & 34 & 27 & 26 & 26 & 30 & 28 & 29 & 51 & 43 & 17 & 52 & 42 & 41 & 49 & 46 & 31\end{array}$ $\begin{array}{llllllllllllllllll}28 & 11 & 31 & 20 & 19 & 21 & 25 & 22 & 23 & 48 & 53 & 26 & 50 & 49 & 40 & 51 & 43 & 12\end{array}$ $\begin{array}{lllllllllllllllll}28 & 36 & 29 & 23 & 23 & 27 & 25 & 26 & 53 & 54 & 37 & 59 & 52 & 46 & 61 & 57 & 29\end{array}$ $\begin{array}{llllllllllllllll}26 & 19 & 18 & 20 & 22 & 19 & 20 & 46 & 52 & 21 & 50 & 40 & 38 & 48 & 37 & 1\end{array}$ $\begin{array}{lllllllllllllll}17 & 19 & 19 & 19 & 21 & 22 & 35 & 38 & 33 & 47 & 49 & 49 & 55 & 55 & 27\end{array}$ $\begin{array}{llllllllllllll}10 & 12 & 14 & 14 & 15 & 33 & 44 & 24 & 50 & 48 & 46 & 56 & 48 & 20\end{array}$ $\begin{array}{lllllllllllll}2 & 12 & 12 & 13 & 35 & 38 & 19 & 50 & 43 & 36 & 51 & 46 & 19\end{array}$ $\begin{array}{llllllllllll}12 & 12 & 13 & 37 & 38 & 21 & 52 & 45 & 38 & 53 & 48 & 21\end{array}$ $\begin{array}{lllllllllll}7 & 8 & 39 & 45 & 27 & 56 & 47 & 44 & 58 & 47 & 23\end{array}$ $\begin{array}{llllllllll}1 & 49 & 44 & 24 & 55 & 46 & 42 & 56 & 45 & 20\end{array}$ $\begin{array}{lllllllll}42 & 45 & 25 & 56 & 47 & 43 & 57 & 46 & 21\end{array}$ $\begin{array}{llllllll}22 & 50 & 67 & 65 & 65 & 70 & 61 & 47\end{array}$ $\begin{array}{lllllll}38 & 63 & 56 & 56 & 62 & 60 & 53\end{array}$ $\begin{array}{llllll}50 & 38 & 37 & 44 & 42 & 22\end{array}$ $\begin{array}{lllll}36 & 36 & 45 & 59 & 51\end{array}$ $\begin{array}{llll}10 & 40 & 51 & 41\end{array}$ $40 \quad 48 \quad 39$ $46 \quad 49$

N.asteroides M.fortuitum M.smegmatis M.navescens M.simiae M.genavense M.terrae M.nonchromogenicum M.xenopi M.gordonae M.bovis M.leprae M.marinum M.scrofulaceum M.gasiri/M.kansasii M.szulgai M.malmoense Mintracellulare M.paratuberculosis M.avium M.intermedium M.intejiectum M.asiaticum M.Helsinki 52157 M.celatum I M.celatum "I M.cookii M. hiberniae

FIG. 3. Hamming distances derived from 16S rRNA sequences. M. Helsinki $52157=M$. branderi $52157^{\Upsilon}$.

and rifampin, a characteristic glycolipid composition (3), and unique fatty acid and alcohol compositions as determined by GLC (Table 2). Three of the strains differed from the strains in the main cluster by producing a yellow pigment whose intensity varied, and two differed by dysgonic growth.

An analysis of the hypervariable region in the 16S rRNA gene sequence, which corresponded to positions known to be specific to mycobacteria at the species level (12), revealed that the strains in the original collection could be placed in three subgroups. Nine strains had an identical, previously undescribed sequence; four strains, including the three pigmented strains, had a sequence identical to that of the recently described taxon M. celatum cluster I (4); and the sequence of one strain, which originally was isolated from a Somalian patient, was identical to that found in the other $M$. celatum cluster (cluster II) (4).

The 16S rRNA gene sequence of strain $52157^{\mathrm{T}}$ (total length, 1,416 nucleotides) is shown in Fig. 1 . This sequence was found in all nine $M$. branderi strains, and it was different from all previously published mycobacterial sequences in the EMBL nucleotide sequence database. The most distinct differences from the M. xenopi, Mycobacterium cookii, Mycobacterium malmoense, Mycobacterium avium, Mycobacterium intracellulare, Mycobacterium scrofulaceum, and $M$. shimoidei sequences were detected at Escherichia coli positions 125 to 185 and 430 to 500 .
The presence of one adenosine at position 458 was another unique property of the sequence. This region corresponds to helix 18 , where rapidly and slowly growing mycobacteria have a short helix and a long helix, respectively. In members of the Mycobacterium terrae-Mycobacterium nonchromogenicum complex, this helix structure is extended by two nucleotides, in comparison with other slowly growing mycobacteria such as $M$. avium (2).

Compared with the sequence of the most similar taxa as determined by biochemical and lipid analyses, $M$. celatum clusters I and II, the $M$. branderi $16 \mathrm{~S}$ rRNA sequence differed by 36 nucleotides after the regions of alignment uncertainty were omitted. This corresponds to a level of homology of $97.5 \%$. As Stackebrandt and Goebel (19) state, it is unlikely that at a level of sequence homology of less than $98 \%$ two organisms exhibit more than 60 to $70 \%$ DNA similarity and hence that they are related at the species level. A phylogenetic tree showing the relationship of $M$. branderi to the other mycobacteria (Fig. 2) was constructed by using equally weighted Hamming distances (Fig. 3).

The strains of $M$. branderi which we analyzed were isolated from samples obtained from nine patients, some of whom had cavitary mycobacteriosis of the lungs that was resistant to available drugs. In most cases, repeat samples obtained from each patient were positive for acid-fast bacilli as determined by 


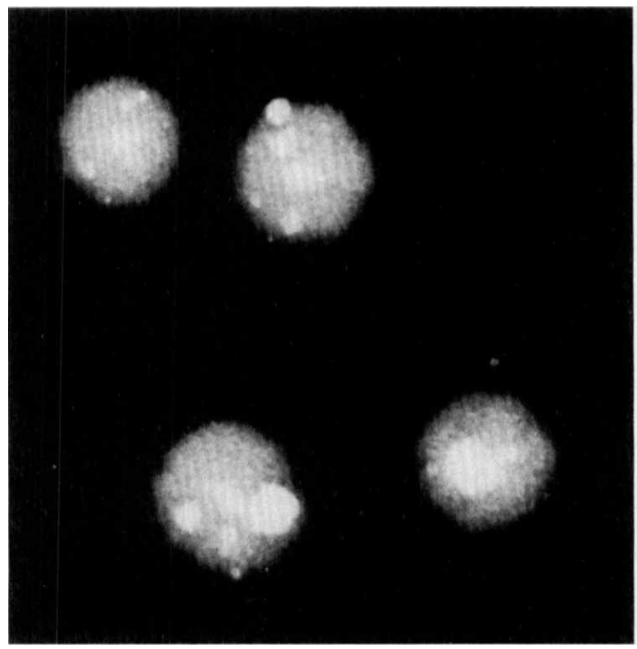

FIG. 4. $M$. branderi colonies on Middlebrook $7 \mathrm{H} 11$ agar. Magnification, $\times 8$.

microscopy, and the only cultivable species was $M$. branderi. Hence, $M$. branderi has to be considered a potential human pathogen.

Taxonomic description of Mycobacterium branderi sp. nov. Mycobacterium branderi (bran' de.ri. L. gen. n. branderi, of Brander, referring to Eljas Brander, the former head of the Tuberculosis Laboratory of the National Public Health Institute, Finland, who collected the strains). The strains that have the newly described sequence are nonchromogenic and produce smooth, often umbonate, off-white to grayish colonies on Middlebrook 7H11 agar (Fig. 4). Growth is equally good at 37 and $45^{\circ} \mathrm{C}$ and is only slightly delayed at $25^{\circ} \mathrm{C}$. In acid-fast staining preparations the bacterial cells, which are 1.2 to $3 \mu \mathrm{m}$ long, are delicate slender rods that are often slightly curved. The strains are negative for Tween 80 hydrolysis, catalase, urease, and nitrate reductase activities (Table 1), and niacin. They are strongly positive for arylsulfatase activity in 14-day tests and moderately to weakly positive for nicotinamidase and pyrazinamidase activities. In susceptibility tests they are resistant to isoniazid, rifampin, pyrazinamide, and cycloserine but susceptible to ethambutol, streptomycin, ethionamide, and capreomycin.

All strains have a glycolipid pattern unlike the patterns of previously described species (3). As determined by thin-layer chromatography, they contain alpha mycolates, ketomycolates, and carboxy mycolates (3). When the fatty acid methyl esters, alcohols, and mycolic acid cleavage products are analyzed by GLC, hexacosanoic acid (26:0) is the major mycolic acid cleavage product and 2-eicosanol (2-OH-20:0alc) is the major alcohol. A high level (15 to $22 \%$ ) of tuberculostearic acid (10-Me18:0) is also present. The type strain is strain 52157, which has been deposited in the American Type Culture Collection as strain ATCC 51789.

Characteristics which differentiate $M$. branderi from related mycobacteria. When conventional and lipid techniques are used, $M$. branderi can be distinguished from $M$. celatum only on the basis of pigment production (Tables 1 and 2). Nonpigmented strains of $M$. celatum can be confused with $M$. branderi unless gene sequencing (12) is used; this occurred in the initiäl classification of the Helsinki group. $M$. branderi can be differentiated from $M$. xenopi, another closely related species, on the basis of the good growth of $M$. branderi that occurs at room temperature, the lack of pigment production by $M$. branderi, and the combination of a high relative amount of 2-eicosanol and the presence of no significant amount of 2-docosanol in $M$. branderi when fatty acid and alcohol compositions are analyzed. Since $M$. cookii is scotochromogenic and does not grow at $37^{\circ} \mathrm{C}(11)$, it poses no difficulty for differentiation. The key characteristic which distinguishes $M$. branderi from $M$. avium and $M$. intracellulare is the presence of a high level of hexacosanoic acid in $M$. branderi as determined by GLC fatty acid analysis, compared with no or insignificant amounts in both $M$. avium and $M$. intracellulare (9). The useful conventional biochemical features for differentiation are the characteristic colony morphology, including the off-white to grayish colony color, the high level of arylsulfatase activity, and susceptibility to ethambutol and streptomycin combined with resistance to cycloserine. Other nonpigmented slowly growing species, including members of the $M$. terrae complex, $M$. malmoense, and $M$. shimoidei, are easily distinguished from $M$. branderi by their inability to grow at $45^{\circ} \mathrm{C}$ and by the results of arylsulfatase and Tween 80 hydrolysis tests (Table 1). GLC analysis of fatty acid compositions provides an excellent way to distinguish these species (Table 2) $(3,9,13)$.

\section{ACKNOWLEDGMENTS}

We are grateful to Päivi Laamanen and Outi Lindroos for technical assistance.

We also thank the Foundation of the Finnish Antituberculosis Association and the Clinical Microbiologists of Finland Foundation (P.K.-K.) for financial support.

\section{REFERENCES}

1. Böttger, E. C. 1989. Rapid determination of bacterial ribosomal RNA sequences by direct sequencing of enzymatically amplified DNA. FEMS Microbiol. Lett. 65:171-176.

2. Böttger, E. C. 1991. Systematik, Differenzierung und Nachweis von bakteriellen Infektionserreger-die Familie Mycobacteriaceae. Immun. Infekt. 19: 143-152.

3. Brander, E., E. Jantzen, R. Huttunen, A. Juntunen, and M.-L. Katila. 1992. Characterization of a distinct group of slowly growing mycobacteria by biochemical tests and lipid analyses. J. Clin. Microbiol. 30:1972-1975.

4. Butler, W. R., S. P. O'Connor, M. A. Yakrus, R. W. Smithwick, B. B. Plikaytis, C. M. Moss, M. M. Floyd, C. L. Woodley, J. O. Kilburn, F. S. Vadney, and W. M. Gross. 1993. Mycobacterium celatum sp. nov. Int. J. Syst. Bacteriol. 43:539-548.

5. Dear, S., and R. Staden. 1991. A sequence assembly and editing for efficient management of large projects. Nucleic Acids Res. 19:3907-3911.

6. Edwards, U., T. Rogall, H., Blöcker, M. Emde, and E. C. Böttger. 1989 Isolation and direct complete determination of entire genes. Characterization of a gene coding for $16 S$ ribosomal RNA. Nucleic Acids Res. 17:78437853.

7. Holt, J. G., N. R. Krieg, P. H. A. Sneath, J. T. Staley, and S. T. Williams (ed). 1994. Bergey's manual of determinative bacteriology, 9 th ed., p. 597-603. Williams \& Wilkins, Baltimore.

8. Hultman, T., S. Bergh, T. Moks, and M. Uhlen. 1991. Bidirectional solidphase sequencing of in vitro-amplified DNA. Biotechniques 10:84-93.

9. Jantzen, E., T. Tangen, and J. Eng. 1989. Gas chromatography of mycobacterial fatty acids and alcohols: diagnostic applications. APMIS 97: 1037-1045.

10. Katila, M. L., E. Brander, E. Jantzen, R. Huttunen, and L. Linkosalo. 1991 Chemotypes of Mycobacterium malmoense based on glycolipid profiles. J. Clin. Microbiol. 29:355-358.

11. Kazda, J., E. Stackebrandt, J. Smida, D. E. Minnikin, M. Daffe, J. H. Partlett, and C. Pitulle. 1990. Mycobacterium cookii sp. nov. Int. J. Syst. Bacteriol. 40:217-223.

12. Kirschner, P., B. Springer, U. Vogel, A. Meier, A. Wrede, M. Kiekenbeck, F.-C. Bange, and E. C. Böttger. 1993. Genotypic identification of mycobacteria by nucleic acid sequence determination: report of a 2-year experience in a clinical laboratory. J. Clin. Microbiol. 31:2882-2889.

13. Luquin, M., V. Ausina, F. Lopez Calahorra, F. Belda, M. Garcia Barcelo, C Celma, and G. Prats. 1991. Evaluation of practical chromatographic procedures for identification of clinical isolates of mycobacteria. J. Clin. Microbiol. 29:120-130.

14. Meier, A., P. Kirschner, K.-H. Schröder, J. Wolters, R. M. Kroppenstedt, and E. C. Böttger. 1993. Mycobacterium intermedium sp. nov. Int. J. Syst. Bacteriol. 43:204-209.

15. Rogall, T., J. Wolters, T. Flohr, and E. C. Böttger. 1990. Towards a phylogeny and definition of species at the molecular level within the genus Myco- 
bacterium. Int. J. Syst. Bacteriol. 40:323-330.

16. Saris, P. E. J., L. Paulin, and M. Uhlen. 1990. Direct amplification of DNA from colonies of Bacillus subtilis and Escherichia coli by the polymerase chain reaction. J. Microbiol. Methods 11:121-126.

17. Shinnick, T. M., and R. C. Good. 1994. Mycobacterial taxonomy. Eur. J. Clin. Microbiol. Infect. Dis. 13:884-901.

18. Sourdis, J., and M. Nei. 1988. Relative efficacies of the maximum parsimony and distance-matrix methods in obtaining the correct phylogenetic tree. Mol. Biol. Evol, 5:298-311.
19. Stackebrandt, E., and B. M. Goebel. 1994. Taxonomic note: a place for DNA-DNA reassociation and 16S rRNA sequence analysis in the present species definition in bacteriology. Int. J. Syst. Bacteriol. 44:846-849.

20. Tsukamura, M. 1982. Mycobacterium shimoidei sp. nov., nom. rev., a lung pathogen. Int. J. Syst. Bacteriol. 32:67-69.

21. Wayne, L. G., and G. P. Kubica. 1986. Mycobacteriaceae, p. 1436-1457. In P. H. A. Sneath, N. S. Mair, M. E. Sharpe, and J. G. Holt (ed.), Bergey's manual of systematic bacteriology, vol. 2. Williams \& Wilkins, Baltimore 